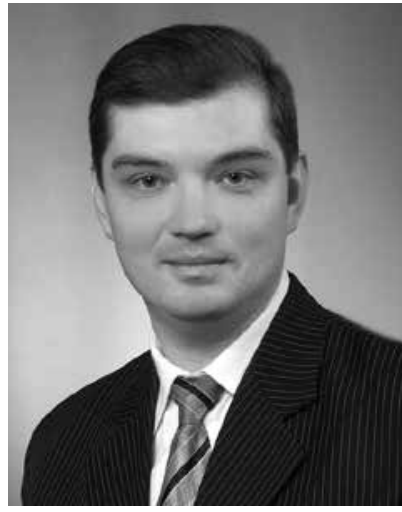

Грібов М.Л., доктор юридичних наук, старший науковий співробітник, професор кафедри оперативно-розшукової діяльності Національної академії внутрішніх справ ORCID ID: 0000-0003-2437-5598 заслужений юрист Украӥни, професор кафедри кримінального процесу
криміналістики Університету державноі фіскальної служби Украӥни ORCID ID: 0000-0002-8921-2039

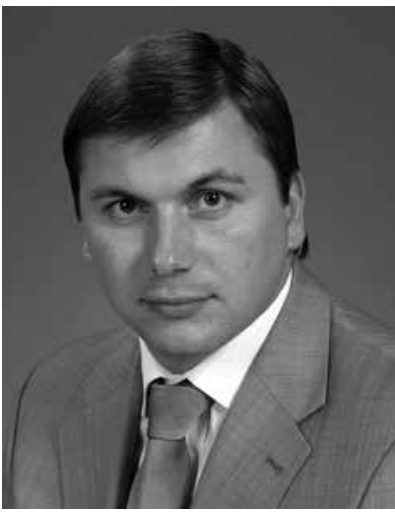

DOI: https://doi.org/10.17721/2413-5372.2019.4/33-44

УДК 343.14:351.745.7:343.974

КОНСПІРАЦІЯ ЯК СИСТЕМА ЗАХОДІВ ЗАБЕЗПЕЧЕННЯ НЕГЛАСНОСТІ КРИМІНАЛЬНО-ПРОЦЕСУАЛЬНОЇ ТА ОПЕРАТИВНО-РОЗШУКОВОЇ ДІЯЛЬНОСТІ ОПЕРАТИВНИХ ПІДРОЗДІЛІВ ПРАВООХОРОННИХ ОРГАНІВ

Анотація. Констатується, що правове регулювання питань конспірації діяльності оперативних підрозділів є неповним, безсистемним. На законодавчому рівні воно представлено кількома нормами, що не лише не урегульовують основи вирішення вказаних питань, а й завдають икоди, обмежуючи можливості реалізації потужного потенціалу оперативних підрозділів у боротьбі зі злочинністю. Розробники підзаконних нормативно-правових актів, спираючись на своє суб'єктивне розуміння змісту конспірації, намагаються пристосувати недолугі новації законодавця до практики. Як наслідок, підзаконні нормативно-правові акти переповнені нечіткими, суперечливими нормами щодо забезпечення конспірації, дотримання їі правил і відповідальності за їх порушення. При цьому таких правил не сформульовано у жодній з відомчих інструкцій, а наявні методичні рекомендації здебільшого застарілі, не мають наукового обгрунтування та торкаються лише певних аспектів конспірації. Відсут- 
ність належного правового регулювання та методичного забезпечення питань конспірації спричиняє проблеми в її організації. Усе це призводить до грубих помилок у роботі, відповідно до відсутності результатів тривалих оперативних розробок, провалу конкретних ОРЗ і НСРД, значних невиправданих затрат людської праці та матеріальних ресурсів, а головне - до травмування й загибелі оперативних працівників, негласних співробітників, а в окремих випадках їх родичів і пересічних громадян.

Чи не головна причина такого становища - відсутність теоретичних основ конспірації діяльності оперативних підрозділів вітчизняних правоохоронних органів.

Mета дослідження - формулювання теоретичних основ конспірації діяльності оперативних підрозділів та висунення пропозицій щодо їх практичної реалізації у фрормі внесення пропозицій щодо змін і доповнень до законодавчих та підзаконних нормативно-правових актів.

У статmі визначено поняття та розкрито зміст конспірації діяльності оперативних підрозділів з внесенням пропозицій щодо унормування відповідних положень. Запропоновано концептуальні засади правового регулювання конспірації діяльності оперативних підрозділів.

Розроблено шляхи вдосконалення правового регулювання охорони інформації щодо діяльності оперативних підрозділів. Розкрито зміст і сформулювало поняття легендування, маскування та оперативного прикриття в діяльності оперативних підрозділів, запропоновано засоби вдосконалення їх юридичної регламентації.

Сфрормульовано поняття та розкрито зміст організації конспірації діяльності оперативних підрозділів. Здійснено оцінку правового регулювання та визначено шляхи вирішення практичних проблем організації конспірації функціонування негласних сил оперативних підрозділів.

Ключові слова: конспірація, дезінформація, державна таємниця, оперативні підрозділи, легендування, маскування, оперативно-розшукові заходи.

П остановка проблеми. Першими статтями Конституції України визначено статус нашої держави як суверенної, незалежної, демократичної, соціальної, правової; закріплено цілісність та недоторканість ii території; встановлено, що людина, ii життя і здоров'я, честь і гідність, недоторканність і безпека є найвищою соціальною цінністю. Повноцінне втілення в життя цих норм перебуває у прямій залежності від ефективності роботи правоохоронних органів, зокрема, від їх здатності протидіяти злочинності.

Основною ланкою правоохоронних органів, на яку державою покладено обов'язок із запобігання злочинам, їх вчасного виявлення, припинення, а також забезпечення якісного розслідування, $є$ оперативні підрозділи. Їх діяльність може бути ефективною лише за умови іiі негласності, збереження у суворій таємниці інформації про проведення конкретних оперативних розробок, оперативно-розшукових заходів (OP3) та негласних слідчих (розшуко- вих) дій (НСРД). Це є досить складним завданням, незважаючи на те, що досвід негласної роботи правоохоронних, розвідувальних і контррозвідувальних органів накопичувався тисячоліттями. Адже сучасним злочинним формуванням, які діють на території України, притаманний високий рівень організації, створення власної розвідки та контррозвідки, використання у протиправних цілях останніх досягнень науки і техніки, наявність корумпованих зв'язків й власної агентурної мережі в органах державної влади, місцевого самоврядування, у прокуратурі, поліції тощо. Крім того, добра обізнаність професійних злочинців 3 методами ОРД дозволяє їм викривати факти проведення ОРЗ та НСРД й чинити активну протидію ОРД та досудовому розслідуванню. Усе це зумовлює необхідність високого рівня конспірації діяльності оперативних підрозділів. Але в реальності цей рівень значно нижчий від наявних потреб. Це визнають 87,6\% опитаних нами оперативних працівників; 47,4\% 3 них стикалися 3 випадками 
витоку таємної оперативної інформації, a $52,1 \%$ - 3 випадками викриття оперативних працівників при проведенні негласних заходів. При цьому 85,3\% опитаних вказують, що службові розслідування проводяться лише по одиницях iз загального числа. Відповідно, реальні масштаби порушень конспірації за офіційними даними відстежити неможливо.

Правове регулювання питань конспірації діяльності оперативних підрозділів $\epsilon$ неповним, безсистемним. На законодавчому рівні воно представлено кількома нормами, що не лише не урегульовують основи вирішення вказаних питань, а й завдають шкоди, обмежуючи можливості реалізації потужного потенціалу оперативних підрозділів у боротьбі зі злочинністю. Розробники підзаконних нормативно-правових актів, спираючись на своє суб'єктивне розуміння змісту конспірації, намагаються пристосувати недолугі новації законодавця до практики. Як наслідок, підзаконні нормативно-правові акти переповнені нечіткими, суперечливими нормами щодо забезпечення конспірації, дотримання їі правил і відповідальності за їх порушення. При цьому, таких правил не сформульовано у жодній з відомчих інструкцій, а наявні методичні рекомендації здебільшого застарілі, не мають наукового обгрунтування та торкаються лише певних аспектів конспірації. Відсутність належного правового регулювання та методичного забезпечення питань конспірації спричиняє проблеми іiї організації. Усе це призводить до грубих помилок у роботі, відповідно до відсутності результатів тривалих оперативних розробок, провалу конкретних ОРЗ і НСРД, значних невиправданих затрат людської праці та матеріальних ресурсів, а головне до травмування й загибелі оперативних працівників, негласних співробітників, а в окремих випадках їх родичів і пересічних громадян.

Чи не головну причину такого становища вбачаємо у відсутності теоретичних основ конспірації діяльності оперативних підрозділів вітчизняних правоохоронних органів.

Аналіз останніх досліджень і публікацій. Окремі питання конспірації у роботі правоохороннихорганів розглядаливітчизняні науковці: С.В. Албул, О.А. Білічак, В.І. Василинчук, А.М. Кислий, О.І. Козаченко, Є.Д. Лук'янчиков, В.А. Некрасов, Д.Й. Никифорчук, Ю.Ю. Орлов, М.А. Погорецький, В.Д. Пчолкін, О.В. Розвадовський, Д.Б. Сергєєва, О.С. Старенький, М.П. Стрельбицький, В.С. Тарасенко, Л.Д. Удалова, С.С. Чернявський, Ю.М. Чорноус, В.В. Шендрик та ін. Однак їхні роботи присвячено вирішенню інших проблем, а питання конспірації вивчалися ними лише фрагментарно - щодо конкретних аспектів кримінального процесу, криміналістики, оперативно-розшукової та контррозвідувальної діяльності. Комплексного дослідження теорії та практики конспірації діяльності оперативних підрозділів в Україні не проводилося.

Мета дослідження - формулювання теоретичних основ конспірації діяльності оперативних підрозділів та висунення пропозицій щодо їх практичної реалізації у формі внесення пропозицій щодо змін і доповнень до законодавчих та підзаконних нормативно-правових актів.

Виклад основного матеріалу. Термін «конспірація» сьогодні широко вживається у законодавчих та підзаконних нормативно-правових актах України та країн пострадянського простору, що регламентують діяльність органів, компетенцію яких становить боротьба зі злочинністю та захист державної безпеки. Цим терміном постійно послуговуються теоретики оперативно-розшукової діяльності та кримінального процесу. Він міцно укорінився у професійному спілкуванні працівників оперативних підрозділів. Проте до сьогодні його зміст не унормовано юридично. Невизначеність термінології призводить до виникнення серйозних проблем у правовому регулюванні та організації забезпечення конспірації. 
Оскільки конспірація має чітко виражену соціальну природу (становить основу певного виду суспільних відносин), але не має юридичного визначення та єдиного теоретичного розуміння, виникає необхідність іï дослідження у площині сутності, призначення та доцільності правового регулювання.

Проведені нами наукові розвідки дозволити встановити наступне. У країнах, населення яких розмовляє західноєвропейськими мовами, «конспірація» як термін $є$ відображенням таємної діяльності суто нелегальних та незаконних організацій, які використовують складну систему заходів для забезпечення свого лиходійства ${ }^{1}$. Саме у цьому значенні його використовують у правотворчому процесі. Запозичення цього терміна для позначення принципів, засад, заходів та діяльності оперативних підрозділів правоохоронних органів України та інших країн пострадянського простору $\epsilon$ результатом природного процесу історичної трансформації його семантичного значення.

Тому вживання терміна «конспірація» може викликати непорозуміння у міжнародних правових відносинах України та іï партнерів. Особливо необхідно звернути увагу на розділи законодавчих актів, де розглядається міжнародне співробітництво. Але зазначене вище не $\epsilon$ перепоною для застосування цього терміна в нормативно-правових актах (ï частинах), які регулюють суспільні відносини, що мають внутрішньодержавний характер (без участі іноземних суб'єктів міжнародного права).

Потрібно мати на увазі, що використання терміна «конспірація» у нормативно-правових актах України має супроводжуватися чіткими, зрозумілими та науково обгрунтованими визначеннями цього та інших пов'язаних 3 ним понять.
Нами було проведено системний аналіз: а) фундаментальних наукових праць, у яких визначено зміст юридичної діяльності, зокрема ОРД, кримінального процесу후 б) законів України та підзаконних нормативно-правових актів; в) практики діяльності оперативних підрозділів різних правоохоронних та розвідувальних органів України. За результатами цього аналізу було встановлено, що унормуванню, серед іншого, підлягають такі основні положення:

1) одним із принципів ОРД $є$ конспіративність - правило таємного, прихованого, невідомого нікому (крім власних суб' сктів) здійснення;

2) принцип конспіративності поширюється не лише на ОРД, а й на всю діяльність оперативних підрозділів, включаючи виконання доручень слідчого, прокурора на проведення НСРД;

3) під конспірацією діяльності оперативних підрозділів потрібно розуміти систему заходів, що спрямовані на забезпечення негласності цієї діяльності;

4) мета конспірації діяльності оперативних підрозділів - збереження у таємниці відомостей про факти, час, місця, коло об'єктів і суб'єктів проведення ОРЗ та НСРД, належність їх суб'єктів і використовуваних ними засобів (приміщень, транспорту, обладнання тощо) до правоохоронних органів;

5) завдання конспірації діяльності оперативних підрозділів - створення в об'єктів ОРЗ та НСРД, їх зв'язків та інших осіб хибних переконань про відсутність задуму і будь-яких дій з пошуку та фіксації фактичних даних про протиправні діяння окремих осіб і груп, відповідальність за які передбачена Кримінальним кодексом України, розвідувально-підривну діяльність спеціальних служб іноземних держав та організацій 3 метою припинення правопорушень і в інтересах кримінального судочинства.

\footnotetext{
1 M Pogoretskyj, O Sukhachov, 'Meaning of the term «conspiration» in the law of Ukraine and other countries' (2014) 6(2) Internal security 69-78.

2 М Погорецький, 'Функціональне призначення оперативно-розшукової діяльності у кримінальному процесі монографрія’ (2007) 153.
} 
У ході проведеного дослідження було обгрунтовано, що зміст конспірації діяльності оперативних підрозділів становлять: охорона відомостей, що становлять таємницю; дезінформування об'єктів ОРЗ та НСРД, їх зв'язків та інших осіб. До заходів охорони відомостей, що становлять таємницю, належать: формальне засекречування цих відомостей; обмеження фізичного доступу до їх носіїв; проведення заходів технічного захисту інформації. До заходів дезінформування належать: легендування (діяльність зі створення легенд), доведення легенд до адресата (маскування та легендоване спілкування), а також підтвердження легенд у разі необхідності (оперативне прикриття).

Сьогодні для заходів із забезпечення оперативними підрозділами негласності власної діяльності бракує належних правових підстав, порядок їх проведення урегульовано незадовільно. Такі підстави існують лише в частині засекречування та охорони інформації щодо негласної діяльності оперативних підрозділів. У частині дезінформування вони фактично відсутні.

Норми статті 273 КПК України не охоплюють повністю тих засобів, що використовуються при проведенні НСРД, а їх реалізація часто виявляється неможливою. Закон України «Про оперативно-розшукову діяльність», дублюючи норми вказаної статті, також не створює належних правових підстав для забезпечення оперативними підрозділами конспірації власної діяльності ${ }^{1}$.

Ураховуючи те, що значна частина заходів забезпечення негласної діяльності оперативних підрозділів за своєю метою та завданнями не збігаються з метою та завданнями ОРД і кримінального процесу, а також те, що легендовані підприємства, установи та організації можуть використовуватись не лише для забезпечення зашифровки місць розташування негласних оперативних підроз- ділів правоохоронних органів, а й певних військових об'єктів, що мають стратегічне або тактичне значення, оборонних підприємств тощо, доцільно питання застосування дезінформації урегульовувати у Законі України «Про державну таємницю», де окремим розділом визначити «Заходи із запобігання викриттю секретної інформації».

При цьому у Кримінальному процесуальному кодексі України та Законі України «Про оперативно-розшукову діяльність» має бути зазначено, що забезпечення оперативними підрозділами негласності власної таємної діяльності здійснюється у порядку та на підставах, передбачених Законом України «Про державну таємницю». Питання фінансування конспірації діяльності оперативних підрозділів та їх взаємодії з іншими державними структурами 3 питань забезпечення негласності власної діяльності потрібно врегулювати на рівні постанови Кабінету Міністрів України.

Зокрема, доцільно ст. 1 у Закону України «Про державну таємницю» доповнити таким визначенням: «Викриття секретної інформації - це одержання відомостей, що становлять державну таємницю особами, які не мають допуску та (або) доступу до таких відомостей шляхом аналізу зовнішніх проявів та результатів діяльності, яка становить предмет засекречування»; доповнити цей Закон статтями 36-1; 36-2; 36-3, які об'єднати в окремий розділ «Заходи запобігання викриттю секретної інформації», виклавши їх у такій редакції:

«Стаття 36-1. Військові формування та підприємства військово-промислового комплексу (якщо їх місце розташування, зміст їх діяльності та (або) іiі результати є державною таємницею), а також оперативні підрозділи державних органів, що визначенні у ст. 5 Закону України «Про оперативно-розшукову діяльність» та у ст. 41 Кримінального процесуального кодексу України уповноважені прово-

М Грібов, 'Засоби, що використовуються під час проведення негласних слідчих (розшукових) дій' (2014) 9 Бюлетень міністерства юстиції України 152-158. 
дити заходи запобігання викриттю секретної інформації.

Стаття 36-2. До заходів запобігання викриттю секретної інформації належать:

1. Розробка та розповсюдження відомостей, що не відповідають дійсності (дезінформації), з метою:

запобігти викриттю місць таємного розташування військових формувань, їх окремих підрозділів, підприємств військово-промислового комплексу, розташування службових приміщень негласних оперативних підрозділів та інших приміщень, що негласно використовуються під час оперативно-розшукової та контррозвідувальної діяльності, проведення негласних слідчих (розшукових) дій під час досудового розслідування;

запобігти викриттю негласних сил та засобів оперативних підрозділів правоохоронних органів, військових формувань та підприємств військово-промислового комплексу;

приховати дані про факт, час, місце, об'єкти і суб' єктів оперативно-розшукових та контррозвідувальних заходів, негласних слідчих (розшукових) дій, коло осіб, залучених до їх проведення.

2. Виготовлення та використання документів, що зашифровують особу та відомчу належність службовців військових формувань, їх окремих підрозділів, працівників підприємств військово-промислового комплексу, негласних штатних та позаштатних працівників оперативних підрозділів.

3. Виготовлення й використання документів, що зашифровують відомчу належність та дійсне призначення приміщень й транспортних засобів, технічного та іншого обладнання, приладів, механізмів.

4. Виготовлення, придбання та використання засобів, що змінюють зовнішній вигляд або загалом приховують наявність будівель, споруд, транспортних засобів, військової техніки, технічного та іншого обладнання, приладів, механізмів.

Стаття 36-3. Порядок виготовлення та використання документів, що зашифровують особу та відомчу належність службовців військових формувань, їх окремих підрозділів, працівників підприємств військово-промислового комплексу, негласних штатних та позаштатних працівників оперативних підрозділів, а також порядок виготовлення та використання документів, що зашифровують відомчу належність та дійсне призначення приміщень й транспортних засобів, технічного й іншого обладнання, приладів, механізмів встановлюється Кабінетом Міністрів України.

Порядок виготовлення, придбання та використання засобів, що змінюють зовнішній вигляд або загалом приховують наявність будівель, споруд, транспортних засобів, військової техніки, технічного та іншого обладнання, приладів, механізмів, встановлюється підзаконними нормативно-правовим актами Міністерства оборони України, МВС України».

Аналіз законодавства та підзаконних нормативно-правових актів України в галузі державної таємниці засвідчує, що віднесення до такої таємниці значної частини відомостей про діяльність оперативних підрозділів не відповідає принципам обгрунтованості та раціональності. Зокрема, йдеться про зміст, форми, методи, організаційні основи та загальні положення тактики ОРД, інформація про які сьогодні є загальнодоступною ${ }^{1}$. Конкретними прикладами цього $є$ такі методи (заходи) ОРД, як візуальне спостереження, оперативний огляд, оперативне опитування, оперативно-технічні заходи та оперативне впровадження до злочинних формувань. Детальна інформація про зміст цих методів (заходів) є публічно доступною в мережі Інтернет, науковій, науково-популярній та публіцистичній літературі, а процес практичного втілен-

1 М Погорецький, О Сухачов, 'Система засобів охорони державної таємниці щодо діяльності оперативних підрозділів правоохоронних органів’ (2016) 25 Журнал східноєвропейського права 24-37. 
ня цих методів яскраво проілюстрований у художніх та документальних фільмах.

Недоцільність засекречування вказаних відомостей також може бути обгрунтована 3 економічних, політичних та юридичних позицій. При цьому державну таємницю мають становити дані щодо конкретних легенд і засобів маскування, які розробляються для проведення конкретних ОРЗ та НСРД. Як складові конспірації вони становлять частину оперативної тактики. У зв'язку з викладеним доцільно у ЗВДТ запровадити та використовувати такі традиційні для ОРД поняття, як дезінформація, легенда, легендування, засоби маскування та документи оперативного прикриття. Це дасть змогу сформулювати положення щодо змісту відомостей, які становлять державну таємницю у сфеpi охорони правопорядку та боротьби зі злочинністю, таким чином, щоб не витрачати ресурси на засекречування загальновідомих відомостей. Цей висновок підтримали $72 \%$ опитаних нами оперативних працівників.

Сьогодні система визначених законом заходів охорони таємниці щодо діяльності оперативних підрозділів має вади як у частині власної організації, так і практичної реалізації положень законодавства. Для іiї вдосконалення доцільно на законодавчому рівні класифікувати заходи 3 охорони державної таємниці на організаційні, технічні, криптографічні та заходи $з$ перевірки осіб у зв'язку 3 наданням допуску до державної таємниці (з відповідними визначеннями) ${ }^{1}$.

У ході дослідження нами було проведено критичний аналіз визначення поняття «легенда», що подавалися вченими, починаючи з 1976 року по теперішній час. У результаті сформульовано авторське визначення цього поняття (легенда в діяльності оперативних підрозділів - спеціально підготовлені відомості, що використовуються для приховування інформації про факт, час, місце, об'єкти і суб'єкти ОРЗ та НСРД, коло осіб, залучених до їх проведення, а також для запобігання викриттю негласних сил і засобів оперативних підрозділів).

Виходячи з цього, з урахуванням результатів критичного аналізу сучасних підходів до визначення категорії «легендування» та розуміння змісту конспірації діяльності оперативних підрозділів, пропонуємо чітко розмежовувати легендування та використання легенди (інший вид діяльності, який охоплює маскування та легендоване спілкування). При цьому легендування слід визначити як діяльність оперативних підрозділів 3 підготовки комплексу відомостей, що використовуються 3 метою приховування інформації про факт, час, місце, об'єкти і суб'єкти ОРЗ та НСРД, коло осіб, залучених до їх проведення, запобігання викриття негласних сил і засобів оперативних підрозділів. Результатом легендування є легенда, що входить до змісту конспірації як складова дезінформування, яке, крім легенди, зараховує ще й засоби доведення іiї до адресата.

Від легендування слід відмежовувати оперативне прикриття, яке потрібно вважати комплексом засобів, що використовуються для підтвердження легенди, використовуваної при проведенні оперативно-розшукових, контррозвідувальних заходів і НСРД, шляхом повторного (додаткового) дезінформування об'єктів впливу.

Від зазначених видів діяльності слід відокремити маскування. Маскування в діяльності оперативних підрозділів $\epsilon$ системою заходів із зовнішніх видозмін або повного припинення можливості візуального сприйняття (фізичного приховування) сил і засобів цих підрозділів 3 метою перешкоджання їх розпізнаванню як таких, що мають відношення до правоохоронних органів та їх діяльності, а також унеможливлення ідентифікації конкретних осіб, приміщень і транспортних засобів.

\footnotetext{
М Погорецький, О Сухачов, 'Система засобів охорони державної таємниці щодо діяльності оперативних підрозділів правоохоронних органів’ 25 (2016) Журнал східноєвропейського права 24-37.
} 
Шляхом комплексного аналізу усталених наукових положень теорії державного управління та ОРД, а також практики діяльності оперативних підрозділів встановлено, що організацією конспірації діяльності оперативних підрозділів варто вважати систему дій посадових осіб суб' єктів ОРД із заснування та впорядкування (налагодження) процесу управління (його окремих стадій) у сфеpi забезпечення негласності функціонування оперативних підрозділів.

Зміст організації конспірації діяльності оперативних підрозділів має три основні компоненти. Перший (стратегічний) - організація конспірації функціонування негласних сил і засобів. Другий - організація конспірації провадження у конкретній справі (оперативного пошуку, оперативно-розшуковій; оперативно-розшукового супроводження кримінального провадження). Третій організація конспірації конкретних ОР3 та НСРД. На кожному з цих рівнів організації підлягає: охорона відповідних відомостей; маскування; легендоване спілкування (легендування та використання засобів доведення легенд до адресата); оперативне прикриття.

Спираючись на аналіз кримінального процесуального та оперативно-розшукового законодавства, а також результатів останніх наукових досліджень ${ }^{1}$, показано, що 3 прийняттям у 2012 році КПК України зміст організації діяльності оперативних підрозділів було розширено за рахунок виконання ними доручень слідчого, прокурора на проведення НСРД. Відповідно й організаційно-правові проблеми, що виникли iз запровадженням інституту НСРД у діяльності оперативних підрозділів, відбилися на організації їх діяльності, зокрема, на організації іiі конспірації. Увагу акцентовано на необхідності вирішення окремих 3 цих проблем шляхом унормування організації діяльності оперативних підрозділів (відповідно і питань конспірації) у межах трьох видів справ: оперативного пошуку, ОРС і справ оперативно-розшукового супроводження кримінального провадження. При цьому організація конспірації в межах кожної 3 названих справ матиме свої особливості, але іiі основні елементи залишаться незмінними та відповідатимуть елементам організації ОРД.

На основі аналізу нормативно-правових актів, наукових праць і навчальної літератури нами було обгрунтовано, що силами оперативних підрозділів потрібно вважати сукупність їх посадових осіб i громадян, залучених ними на добровільній основі до виконання завдань ОРД й доручень слідчого, прокурора на проведення НСРД.

При цьому негласними силами оперативних підрозділів слід уважати сукупність їх посадових осіб (відомості щодо факту служби яких у правоохоронному органі не підлягають розголошенню) та громадян, добровільно залучених на конфіденційній основі до конспіративного виконання завдань ОРД і дору-

\footnotetext{
В Уваров, 'Проблеми правової регламентації інституту негласних слідчих (розшукових) дій’ (2017) 3 Bicник Національної академії прокуратури України 19-24; М Грібов, 'Проведення негласних слідчих (розшукових) дій щодо особи за її згодою' (2018) 1 Науковий вісник Національної академії внутрішніх справ 87-95; Д Сергєєва, 'Використання результатів негласних слідчих (розшукових) дій у доказуванні: щодо удосконалення норм чинного КПК України' (2016) 1 Південноукраїнський правничий часопис 105-107; М Погорецький, 'Негласні слідчі (розшукові) дії: проблеми провадження та використання результатів у доказуванні' (2013) 1 Юридичний часопис Національної академії внутрішніх справ 270-277; М Погорецький, 'Застосування провокації в ході негласних розслідувань: питання правомірності' (2016) 1 Вісник кримінального судочинства 33-42; О Старенький, М Цуцкірідзе, 'Використання негласних слідчих (розшукових) дій як засобів доказування в кримінальному провадженні на досудовому розслідуванні' (2015) Право України 152-161; О Старенький, 'Проблемні аспекти законодавчої регламентації провадження негласних слідчих (розшукових) дій' (2013) 4 Науковий вісник Дніпропетровського державного університету внутрішніх справ 449-455; М Стащак, Л Мазур, 'Проблемні аспекти застосування негласних слідчих (розшукових) дій оперативними підрозділами ОВС України' (2012) 6 (84) Митна справа 85-89; О Татаров, 'Окремі проблеми при проведенні негласних слідчих (розшукових) дій' (2016) 3 Вісник кримінального судочинства 69-77; С Чернявський, Л Удалова, '‘рунтовне дослідження теорії та практики функції обвинувачення у кримінальному провадженні України' (2016) 4 Вісник кримінального судочинства 199-202.
} 
чень слідчого, прокурора на проведення НСРД. До негласних сил оперативних підрозділів належать штатні та позаштатні працівники, яких у відомчих нормативно-правових актах доцільно диференціювати на окремі категорії залежно від спеціалізації виконання ними конкретних завдань у межах ОРД та кримінального процесу. Для кожної категорії потрібно розробляти індивідуальну методику забезпечення конспірації, основи якої мають бути унормовані.

Відповідно до чинного законодавства негласні позаштатні працівники оперативних підрозділів з об'єктивних причин не можуть бути допущені до державної таємниці. Водночас вони щонайменше мають бути ознайомлені $з$ організацією і тактикою агентурної роботи, 3 основами забезпечення іï конспірації, володіти особливостями таких негласних методів одержання інформації, як розвідувальне опитування, візуальне спостереження. При залученні до конкретних ОР3 та НСРД вони мають бути ознайомлені 3 конкретними об'єктами, часом і місцем їх проведення. Часто виникають ситуації, коли одні негласні співробітники мають бути проінформовані про персональні дані, завдання та результати діяльності інших. У зв'язку з викладеним запропоновано у Законі України «Про державну таємницю» передбачити можливість доступу до секретної інформації оперативного характеру особам, залученим до конфіденційного співробітництва, без надання доступу (в обсязі, необхідному для виконання покладених на них завдань).

За результатами аналізу практичної діяльності оперативних підрозділів запропоновано заходи щодо удосконалення організації конспірації у сфері конфіденційного співробітництва, зокрема: зменшення обсягу документообігу, збільшення фінансування, урізноманітнення заходів забезпечення таємниці особистих зустрічей та спілкування різними каналами зв'язку.

На основі порівняльного аналізу положень наукових праць щодо понят- тя та переліку засобів ОРД, розуміння змісту конспірації, а також з урахуванням сучасних правових реалій подано авторське визначення засобів конспірації діяльності оперативних підрозділів (у вузькому розумінні - це сукупність знаряддя (матеріального інструментарію) та науково обгрунтованих прийомів його правомірного застосування, що використовуються цими підрозділами для забезпечення негласності проведення ОРЗ та НСРД. У широкому розумінні засобами забезпечення конспірації $\epsilon$ все те, за допомогою чого досягається негласність ОРЗ та НСРД).

До засобів забезпечення конспірації (у вузькому розумінні) віднесено: засоби маскування, засоби імітації та документи прикриття (документи, що засвідчують особу, належність рухомого та нерухомого майна, офіційні листи, медичну, кадрову, технічну та іншу документацію). Запропоновано запровадити єдині підходи до визначення поняття, змісту та переліку засобів забезпечення конспірації у нормативно-правових актах різних відомств.

Поряд із засобами конспірації діяльності оперативних підрозділів досліджується і питання конспірації використання інших засобів: оперативних та інших обліків; розвідувальних комп'ютерних програм; приміщень; оперативної техніки. Визначено наявні у цій сфері проблеми та запропоновано шляхи їх вирішення. Зокрема, обгрунтовано, що вдосконалення забезпечення конспірації використання конкретних засобів можна досягти шляхом запозичення корисних, раціональних, ефективних норм, що містять акти одних відомств до актів інших.

Висновки. Конспірація як система заходів забезпечення негласності кримінально-процесуальної та оперативно-розшукової діяльності оперативних підрозділів правоохоронних органів сьогодні не знаходить належного закріплення у законодавстві України та у положеннях підзаконних нормативно-правових актів. 
Це призводить до невизначеності у важливих питаннях діяльності оперативних підрозділів, грубих помилок у роботі, відповідно до відсутності результатів тривалих оперативних розробок, провалу конкретних ОРЗ і НСРД, значних невиправданих затрат людської праці та матеріальних ресурсів, а головне - до травмування й загибелі оперативних працівників, негласних співробітників, а в окремих випадках їх родичів і пересічних громадян.

Для виправлення цього становища необхідні наступні системні зміни.

По-перше, правове регулювання конспірації діяльності оперативних підрозділів має здійснюватися у суворій відповідності до Конституції України та засновуватись на нормах Закону України «Про державну таємницю», де окремим розділом потрібно регламентувати конкретні заходи, що можуть застосовуватися 3 метою запобігання розкриття засекречених у встановленому порядку відомостей, у тому числі й за допомогою дезінформації. У Кримінальному процесуальному кодексі України та Законі України «Про оперативно-розшукову діяльність» має бути зазначено, що забезпечення оперативними підрозділами негласності власної таємної діяльності здійснюється у порядку та на підставах, передбачених Законом України «Про державну таємницю». Питання фінансування конспірації діяльності оперативних підрозділів та їх взаємодії з іншими державними структурами з питань забезпечення негласності власної діяльності потрібно врегулювати на рівні постанови Кабінету Міністрів України.

По-друге, на рівні законодавства та підзаконних нормативно-правових актів потрібно визначити наступне: одним із принципів ОРД $є$ конспіративність - правило таємного, прихованого, невідомого нікому (крім власних суб'єктів) здійснення; принцип конспіративності поширюється не лише на ОРД, а й на всю діяльність оперативних підрозділів, включаючи виконання дору- чень слідчого, прокурора на проведення НСРД; під конспірацією діяльності оперативних підрозділів потрібно розуміти систему заходів, що спрямовані на забезпечення негласності цієї діяльності; мета конспірації діяльності оперативних підрозділів - збереження у таємниці відомостей про факти, час, місця, коло об'єктів і суб'єктів проведення ОРЗ та НСРД, належність їх суб' єктів і використовуваних ними засобів (приміщень, транспорту, обладнання тощо) до правоохоронних органів; завдання конспірації діяльності оперативних підрозділів - створення в об'єктів ОРЗ та НСРД, їх зв'язків та інших осіб хибних переконань про відсутність задуму і будь-яких дій з пошуку та фіксації фактичних даних про протиправні діяння окремих осіб і груп, відповідальність за які передбачена Кримінальним кодексом України, розвідувально-підривну діяльність спеціальних служб іноземних держав та організацій 3 метою припинення правопорушень і в інтересах кримінального судочинства.

По-третє, у частині проведення оперативними підрозділами конкретних OP3 та НСРД предмет засекречування має становити лише інформація про те де, коли, ким по відношенню до кого та 3 використанням якої дезінформації (легенд і засобів маскування) проводяться конкретні ОРЗ та НСРД. Що стосується стратегічних аспектів діяльності оперативних підрозділів, то засекречуванню підлягають персональні дані усіх негласних працівників (штатних і позаштатних), відомості щодо створених i використовуваних 3 метою забезпечення конспірації підприємств, установ, організацій, приміщень, транспортних засобів. Охорона державної таємниці щодо діяльності оперативних підрозділів здійснюється за допомогою системи заходів, які встановлюються за допомогою норм права. Ці заходи доцільно класифікувати на організаційні, технічні, криптографічні та заходи з перевірки осіб у зв'язку з наданням допуску до державної таємниці. 


\section{REFERENCES}

\section{LIST OF LEGAL DOCUMENTS}

\section{LEGISLATION}

1. Kryminalnyi protsesualnyi kodeks Ukrainy: Zakon Ukrainy [Criminal Procedural Code of Ukraine: Law of Ukraine] vid 13.04.2012 № 4651-VI <http://zakon3.rada.gov.ua/laws/show/4651-17> data zverneniia 03.12.2019 [in Ukrainian].

2. 2. Pro operatyvno-rozshukovu diialnist: Zakon Ukrainy [On Operative and Searching Activity: Law of Ukraine] vid 18. 02. 1992 № 2135-12<https://zakon.rada.gov.ua/go/2135-12> data zverneniia 03.12.2019 [in Ukrainian].

\section{BIBLIOGRAPHY}

\section{AUTHORED BOOKS}

3. Pohoretskyi M, Funktsionalne pryznachennia operatyvno-rozshukovoi diialnosti u kryminalnomu protsesi [Functional appointment of Operative and Searching Activity in the Criminal Process] (Arsis, LTD2007) 576 [in Ukrainian].

\section{ARTICLES}

4. Pogoretskyj M, Sukhachov O, 'Meaning of the term «conspiration» in the law of Ukraine and other countries' 6 (2) (2014) Internal security 69-78 [in Ukrainian].

5. Hribov M, 'Zasoby, shcho vykorystovuiutsia pid chas provedennia nehlasnykh slidchykh (rozshukovykh) dii' [Means used in carrying out unspoken investigative (search) actions] (2014) 9 Biuleten ministerstva yustytsii Ukrainy [Bulletin of the Ministry of Justice of Ukraine] 152-158 [in Ukrainian].

6. Hribov M, 'Provedennia nehlasnykh slidchykh (rozshukovykh) dii shchodo osoby za yii zhodoiu'[Conducting Covert Investigative (Detective) Actions in Respect of a Person with the Person's Consent] (2018) 1 (106) Naukovij visnik Nacional'noi akademii vnutrisnih sprav 87-95 [in Ukrainian].

7. Pohoretskyi M, 'Nehlasni slidchi (rozshukovi) dii: problemy provadzhennia ta vykorystannia rezultativ u dokazuvanni' [Covert investigative (search) actions: problems of proceedings and usingof the resultsin proving] (2013) 1 Yurydychnyi chasopys Natsionalnoi akademii vnutrishnikh sprav 270-277 [in Ukrainian].

8. Pohoretskyi M, 'Zastosuvannia provokatsii $\mathrm{v}$ khodi nehlasnykh rozsliduvan: pytannia pravomirnosti'[The use of provocations during secret investigations: the issue of legality] (2016) 1 Visnyk kryminalnoho sudochynstva 33-42 [in Ukrainian].

9. Serhieieva D, 'Problemni pytannia postanovlennia ukhval pro provedennia nehlasnykh slidchykh (rozshukovykh) dii' [Problematic issues of decision on conducting covert investigative (search) actions] (2014) 1 Visnyk Chernivetskoho fakultetu Natsionalnoho universytetu «Odeska yurydychna akademiia» 177-186 [in Ukrainian].

10. Starenkyi O, 'Problemni aspekty zakonodavchoi rehlamentatsii provadzhennia nehlasnykh slidchykh (rozshukovykh) dii' [Problematic aspects of the legislative regulation of conductingcovert investigative (search) actions] (2013) 4 Naukovyi visnyk Dnipropetrovskoho derzhavnoho universytetu vnutrishnikh sprav 449-455 [in Ukrainian].

11. Stashchak M, Mazur L, 'Problemni aspekty zastosuvannia nehlasnykh slidchykh (rozshukovykh) dii operatyvnymy pidrozdilamy OVS Ukrainy'[Problematic aspects of usingcovert investigative (search) actions by operative subdivisions of Internal Affairs Bodies of Ukraine] (2012) 6 (84) Mytna sprava 85-89 [in Ukrainian].

12. Tsutskiridze M, Starenkyi O, 'Vykorystannia nehlasnykh slidchykh (rozshukovykh) dii yak zasobiv dokazuvannia v kryminalnomu provadzhenni na dosudovomu rozsliduvanniya' [Secret Investigation (Search) Actions as a Means of Proof in Criminal Proceedings in Pre-Trial Investigation] (2015) Pravo Ukrainy 152-161 [in Ukrainian].

13. Uvarov V, 'Problemy pravovoi rehlamentatsii instytutu nehlasnykh slidchykh (rozshukovykh) dii'[Challenges of covered investigative actions legal regulation] (2017) 3 Visnyk Natsionalnoi akademii prokuratury Ukrainy 19-24 [in Ukrainian]. 


\title{
Hribov M.,
}

Doctor of Laws Science, senior Researcher professor of the Department of

Operational and investigative activity NAVS

ORCID ID: 0000-0003-2437-5598

\section{Sukhachov O.,}

Doctor of Laws Science, honored lawyer of Ukraine, professor of the Department of Criminal Process and criminalistics of the University of the state Fiscal service of Ukraine

ORCID ID: 0000-0002-8921-2039

DOI: https://doi.org/10.17721/2413-5372.2019.4/33-44

\section{CONSPIRACY AS A SYSTEM OF MEASURES TO ENSURE THE SECRET OF THE CRIMINAL PROCEDURAL AND INVESTIGATIVE ACTIVITIES OF THE OPERATIONAL LAW ENFORCEMENT UNITS}

\begin{abstract}
Annotation. It is stated that the legal regulation of the matters of conspiracy of activity of operative subdivisions is incomplete, unsystematic. At the legislative level, it is represented by several norms, which not only do not settle the basics for solving these issues, but also are damaging, limiting the possibility of realizing the powerful potential of operational units in the fight against crime. The developers by-laws normative and legal acts, relying on a subjective understanding of the meaning of conspiracy, are trying to tailor the untoward innovation of the legislator to practice. As a consequence, the bylaws of the legal acts are filled with unclear, contradictory norms to ensure conspiracy, adherence to its rules and responsibility for their violation. At the same time, such rules are not formulated in any departmental instructions, and the existing methodological recommendations, mostly, outdated, do not have scientific justification and affect only certain aspects of conspiracy. The lack of proper legal regulation and methodological support for conspiracy issues causes problems of its organization. All this leads to gross errors in the work, and, consequently, to the lack of results of long operational developments, the failure of specific SES and NRD, significant undue costs of human labor and material resources, and most importantly - to the injury and death Operative workers, secret employees, and in some cases their relatives and ordinary citizens. It is not the main reason for such a situation - absence of theoretical foundations of convolutation of the operational units of Ukrainian law enforcement agencies. The purpose of the study is to formulate the theoretical foundations of a conspiration of operational subdivisions and to offer proposals for their practical realization in the form of proposals for changes and additions to the legislative and by-laws normative and legal Acts. The article defines the notion and revealed of the content of conspiracy activities of the operational subdivisions with the introduction of proposals on rationing of the relevant provisions. The conceptual principles of the legal regulation of conspiracy activities of the operational subdivisions are suggested. The ways to improve the legal regulation of information security on activities of operational subdivisions are developed. Revealed the content and formulated the notion of legend, masking and operational cover in the activities of operational subdivisions, the means of improving their legal regulation are offered. The concept and revealed content of the organization of conspiration of operational subdivisions activity is formulated. The assessment of legal regulation is carried out and ways to solve practical problems in the organization of conspiration functioning of the unpublicized forces of operational subdivisions are performed.
\end{abstract}

Keywords: conspiracy, misinformation, state mystery, operational divisions, legend, disguise, investigative activities.

Стаття надійшла до редакиії журналу 05.12.2019. 